\title{
Anatomical and Physicochemical Characterization of the Araucaria angustifolia Seed Coat
}

\author{
Danielle Affonso Sampaio ${ }^{1}$ (D), Rosilei Aparecida Garcia ${ }^{1}$ (D), \\ Helena Regina Pinto Lima² \\ ${ }^{1}$ Departamento de Produtos Florestais, Instituto de Florestas, Universidade Federal Rural do Rio de Janeiro - UFRRJ, \\ Seropédica/RJ, Brasil \\ ${ }^{2}$ Departamento de Botânica, Instituto de Ciências Biológicas e da Saúde, Universidade Federal Rural do Rio de Janeiro - \\ UFRRJ, Seropédica/RJ, Brasil
}

\begin{abstract}
Seed coat plays an important role in the embryo protection and seed germination. This study aimed to characterize the anatomical structure, histochemical and physicochemical aspects of the seed coat of Araucaria angustifolia Kuntze. Light and scanning microscopy usual procedures, and histochemical tests were used to describe and characterize seed layers, as well as to determine their extractive contents. Functional groups of the integument coat layers were observed by Fourier transformed infrared spectroscopy. Color analyses were performed in CIE $1976 \mathrm{~L}^{*} \mathrm{a}^{*} \mathrm{~b}^{*}$ color space. Wettability of the layers was evaluated by contact angle analysis. The anatomical and chemical features observed in the seed layers include the rucose cuticle and the presence of many layers of sclerenchyma in the mesotesta; and the chromaticity due to extractive content and phenolic compounds in the endotesta. The wettability varied among layers according to their structure. These features information contribute to a better understanding on the services provided by the Araucaria angustifolia seed coat.
\end{abstract}

Keywords: pinhão, colorimetry, conifers, contact angle analysis, FT-IR spectroscopy. 


\section{INTRODUCTION}

Araucaria angustifolia (Bertol.) Kuntze belongs to the Araucariaceae and is known as Brazilian pine or Parana pine. This is the only species of this genus with natural occurrence in Brazil (Costa et al., 2013). The species covers an area of natural occurrence of about 200,000 $\mathrm{km}^{2}$ covering the entire Southern Brazil, and to sparse regions in the south of São Paulo and Minas Gerais states, as well as areas of high altitudes in Rio de Janeiro state. Araucaria forest remnants are estimated to cover only $3 \%$ of the original area (APREMAVI, 2017). A. angustifolia has great economic value due to the mechanical and physical properties of the wood. Different parts of this species have been used in the folk medicine in South America, leading to chemical, biological and pharmacological studies (Branco et al., 2016). Commonly known as pinhão, its seed presents high nutritional value (Silva et al., 2011), and is used in human nutrition as a traditional high caloric source content food (NEPA, 2011; Cordoba et al., 2016).

The pinhão is a recalcitrant seed (Silva et al., 2011; Peralta et al., 2016). Sampaio et al. (2016) described the pinhão seed coat consisting of three-layered: exotesta, mesotesta, and endotesta.

Doni et al. (1985) reported that the presence of the external coat delays the germination process of the Pinhão, likely due to the restriction to water inflow (Borges et al., 1987). Studies with the seed coat have been carried out in order to elucidate the influence of coat in the embryo development and seed germination (Muhl et al., 2016; Koen et al., 2017).

The structure of the seed coat is complex and variable among species, and despite of the great importance of $A$. angustifolia seeds, there is no much information in the literature about their coat characters. Enhancing the knowledge about their cell structure and physical and chemical characteristics may allow a correct functional interpretation of seed coat, enabling a better usage of non-timber forest resources.

In this context, this study aimed to investigate the anatomy, the chemical composition, and physical characteristics of each coat layer of the Araucaria angustifolia seeds.

\section{MATERIAL AND METHODS}

\subsection{Study area and plant material}

Mature pinhão seeds used in this study were dispersed by 15 individuals of $A$. angustifolia and collected directly from the ground, from Vale dos Eucaliptos region, Alagoa, Minas Gerais state, in the period of March-April 2014. Seeds presented mean values and \pm standard deviation of $56.0 \pm 3.2 \mathrm{~mm}$ length and $20.4 \pm 1.7 \mathrm{~mm}$ width. Only healthy seeds were sampled.

\subsection{Anatomical characterization}

Seed coats were detached in the three layers, and each one was embedded in Historesin for preparation of histological slides. Cross and longitudinal sections of $5 \mu \mathrm{m}$ were obtained with a Leica RM 2235 rotary microtome. The sections were stained with $0.05 \%$ toluidine blue, according to Kraus \& Arduin (1997).

Bright-field microscopy and fluorescence microscopy were used to evaluate the seed coat tissue components, with a 450-480 $\mathrm{nm}$ blue excitation cube and a FITC filter (U-MWB2), through an OLYMPUS ${ }^{\circ}$ BX 51 optic microscope. Photomicrographs were taken with a XC30 3.0 MP digital camera coupled to the CELL ${ }^{\mathrm{F}}$ image processing digital system. Histochemical tests were performed with fresh material, using Lugol to detect starch (Kraus \& Arduin, 1997), Wiesner test to lignin (Lin \& Dence, 1992), Sudan IV to lipid compounds, and $10 \%$ potassium dichromate $\left(\mathrm{K}_{2} \mathrm{Cr}_{2} \mathrm{O}_{7}\right)$ to phenolic compounds (Kraus \& Arduin, 1997). Scanning electron microscopy (SEM) images were obtained using a HITACHI TM3000.

\subsection{Extractive content}

Each seed coat layer was detached from the kernel and grounded with a Willey mill grinder (SL 31 Model), and the extractive content was determined according to the method described by Abreu et al. (2006). The grounded samples of the three seed coat layers were extracted in a soxhlet-type extractor, using organic solvents of crescent polarity - ciclohexane, ethyl acetate and methanol - for an uninterrupted 24-hour period for each solvent. After each extraction, the extracts were concentrated in a rotary evaporator under vacuum and taken to the exhaust hood for the complete solvent 
evaporation. After this procedure, the extractive content was determined by the following Equation 1:

$$
E C=\left(W_{2} \times 100\right) / W_{1}
$$

where: $E C=$ extractive content $(\%) ; W_{2}=$ weight of the concentrated extract (g); and $W_{1}=$ weight of the dried sample $(\mathrm{g})$. Three replicates were done for each seed coat layer.

\subsection{Fourier Transform Infrared spectroscopy (FT-IR)}

For this analysis, we used dried samples from each seed coat layer without extractives. The samples were grounded in a ball mill until it reached a talc-like appearance, and posteriorly freezed in liquid nitrogen and dried using TERRONI lyophilizer in order to obtain the complete dehydration of the sample. Each sample ( $2 \mathrm{mg}$ ) was mixed in $100 \mathrm{mg}$ potassium bromide (KBr) in a pelletized condition. The spectra were recorded in a VARIAN 640-IR FT-IR spectrometer at transmittance experimental mode, using $4 \mathrm{~cm}^{-1}$ of resolution, 128 scans and spectral amplitude between $4000-400 \mathrm{~cm}^{-1}$.

\subsection{Color spectroscopy}

Colorimetric analysis was performed by the CM 2600d Konica Minolta spectrophotometer on the CIE $1976 \mathrm{~L}^{\star} \mathrm{a}^{\star} \mathrm{b}^{\star}$ color space according to the ISO 11664-4:2008 (ISO, 2008), in which the following variables were obtained: lightness $\left(\mathrm{L}^{*}\right), \mathrm{a}^{\star}$ (variation between green and red) and $b^{\star}$ (variation between blue and yellow) coordinates, chroma $\left(\mathrm{C}^{*}{ }_{\mathrm{ab}}\right)$ and hue angle $\left(h_{a b}\right)$. The $C^{*}{ }_{a b}$ and $h_{a b}$ were calculated by the following Equations 2 and 3:

$C^{*}{ }_{a b}=\left[\left(a^{*}\right)^{2}+\left(b^{*}\right)^{2}\right]^{1 / 2}$

and

$h_{a b}=\arctan \left(b^{*} / a^{*}\right)$

The measurements were done with D65 light, $10^{\circ}$ standard observer, included specular light and $3 \mathrm{~mm}$ aperture (SAV «Small Area View»). Color measurements were performed at both inner and outer surfaces of each seed coat layer, as follows: $S_{1}=$ exotesta outer surface; $\mathrm{S}_{2}=$ exotesta inner surface; $\mathrm{S}_{3}=$ mesotesta outer surface; $\mathrm{S}_{4}=$ mesotesta inner surface; $\mathrm{S}_{5}=$ endotesta outer surface; and $\mathrm{S}_{6}=$ endotesta inner surface. Two color measurements were done per surface per seed, for a total of 50 seeds and 100 observations.

\subsection{Contact angle analysis}

Contact angle analysis were performed with the Drop Shape Analyzer DSA100, version 1.92, Krüss GmbH (Hamburg, Germany), which is composed by a sample table, a video system with camera and a dosing syringe. The DSA1 program, which records drop images on the material surface and analyzes the drop behavior as a function of the time, performed the contact angle measurements.

Contact angle measurements were done at both inner and outer surfaces of each seed coat layer $\left(S_{1}-S_{6}\right)$. $S_{1}$ measurements were performed at a plane seed surface, and modelling clay was used for seed fixing and leveling on the support desk. The seeds were peeled and the coats layers were detached. The detached samples were fixed with adhesive tape in slides for $\mathrm{S}_{2}-\mathrm{S}_{6}$ surface contact angle measurements.

The analysis of 50 seeds was realized in a climate room. Distilled water was used as the liquid test, in addition to a $100 \mu \mathrm{l}$ dosing syringe with a $0.5 \mathrm{~mm}$-diameter needle, which was placed $3 \mathrm{~mm}$ higher from the sample surface. Measurements were made in $15 \mathrm{~s}$ intervals, during $3 \mathrm{~min}$, totalizing 12 contact angles reading for each surface. Three variables were evaluated: mean contact angle $=$ mean of the 12 measures through $180 \mathrm{~s}$; initial angle $=$ first measure, after $15 \mathrm{~s}$; and final angle $=$ last measure, after $180 \mathrm{~s}$.

\section{RESULTS}

\subsection{Anatomical characterization}

The seed coat of $A$. angustifolia develops three integuments: exotesta, mesotesta and endotesta. The outermost layer is composed by a group of fiber-tracheids with tabular and isodiametric cells, which is covered by a thin rucose ornamented cuticle (Figure 1A). This layer, in cross section, has 6-7 layers of fiber-tracheids (Figures $1 \mathrm{~B}$ and 2A-B), which have thick lignified cell walls (mean length $=7.45 \pm 1.95 \mu \mathrm{m}$ ) (Figure 1C), with lipidic compounds in the cells (Figure 1D). These cells in longitudinal sections are long (mean length $=1339.76 \pm 234.44 \mu \mathrm{m})$ (Figures 1E and 2C) and exhibit pits diameter with 

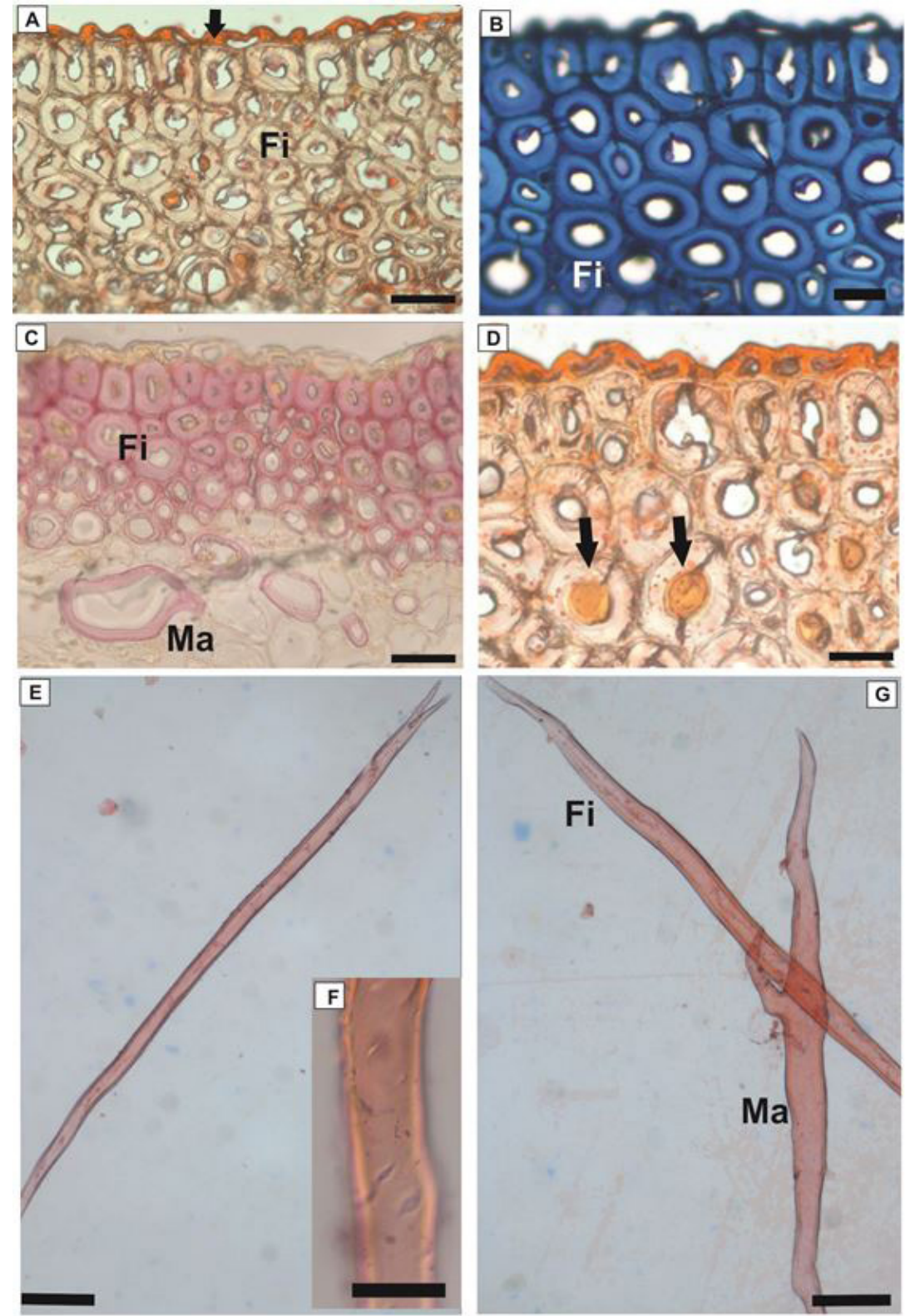

Figure 1. Anatomical features of exotesta on cross sections (A-D) and dissociated material (E-G). $A=$ Rucose cuticular ornamentation (arrow), Sudan IV; B = Isodiametric cells, Toluidine blue; C = Lignified walls, Wiesner test; D = Lipid compounds (arrow), Sudan IV; E = Fiber-tracheids; F = Detail of the pits; G = Macrosclereids and Fiber-tracheids. Fi $=$ Fiber-tracheids; $\mathrm{Ma}=$ Macrosclereids. Bars $=30 \mu \mathrm{m}(\mathrm{A}, \mathrm{C}-\mathrm{D}$ and F); $25 \mu \mathrm{m}(\mathrm{B}, \mathrm{E}$ and G).

$5.80 \pm 1.14 \mu \mathrm{m}$ (Figures 1F and 2D). Besides this tissue, there is a ground parenchyma and macrosclereids idioblasts (Figure 1G). The exotesta has a mean thickness of $268.5 \mu \mathrm{m}$.

The mesotesta, in cross section, exhibits three regions (Figures $3 \mathrm{~A}-\mathrm{B}, 4 \mathrm{~A}-\mathrm{D}$ ). The outer tissue is adjacent to the exotesta $\left(\mathrm{S}_{3}\right)$ and formed by 8-9 layers of lignified isodiametric sclerenquima cells (Figure 3C). Fiber-tracheids and different types of sclereids are found in the mesotesta (Figures 3E-H). The middle region is constituted by cells arranged as a lax net, which shows positive reaction for phenolic compounds in general (Figure 3D). Cross section in the inner tissue $\left(\mathrm{S}_{4}\right)$ shows long cells, with thick wall and reduced lumen 
in longitudinal sections, (Figures 3A-B). The mesotesta has a mean thickness of $246 \mu \mathrm{m}$.

The endotesta, in cross section, is formed by two tissues (Figures 5A and 6A-B). The outer tissue, adjacent to the mesotesta $\left(S_{5}\right)$, exhibits parenchymatic cells with phenolic compounds (Figure 5C-D); the innermost tissue $\left(\mathrm{S}_{6}\right)$ presents parenchymatic cells with a starch grains (Figure 5B and 6A-D). The endotesta has a mean thickness of $86 \mu \mathrm{m}$.

\subsection{Chemical characterization}

The extractive content found was different for the three seed coat layers (Table 1).

\subsection{FT-IR spectroscopy}

In the infrared spectrum of the seed coat layers (Figure 7) we may note a peak around $3400 \mathrm{~cm}^{-1}$, indicating stretching of hydroxyl groups $(\mathrm{O}-\mathrm{H})$ in aliphatic and phenolic structures. The absorption peak at $\sim 1730 \mathrm{~cm}^{-1}$ is assigned to stretching of carbonyl groups $(\mathrm{C}=\mathrm{O})$ in aldehydes or hemicellulose non-conjugated ketones. The peak at $\sim 1600 \mathrm{~cm}^{-1}$ refers to vibration of the aromatic ring, although it is influenced by stretching of the carbonyl groups $(\mathrm{C}=\mathrm{O})$. The peak at $1500 \mathrm{~cm}^{-1}$ is also attributed to the vibration of the aromatic ring. The absorption band at

Table 1. Extractive content of the Araucaria angustifolia seed coat layers.

\begin{tabular}{ccccc} 
& & \multicolumn{3}{c}{ Extractive content (\%) } \\
\cline { 2 - 5 } Layer & Ciclohexane & Ethyl acetate & Methanol & Total \\
Exotesta & 1.260 & 1.679 & 8.971 & 11.910 \\
Mesotesta & 1.104 & 1.660 & 14.676 & 17.440 \\
Endotesta & 0.665 & 0.840 & 26.025 & 27.530 \\
\hline
\end{tabular}
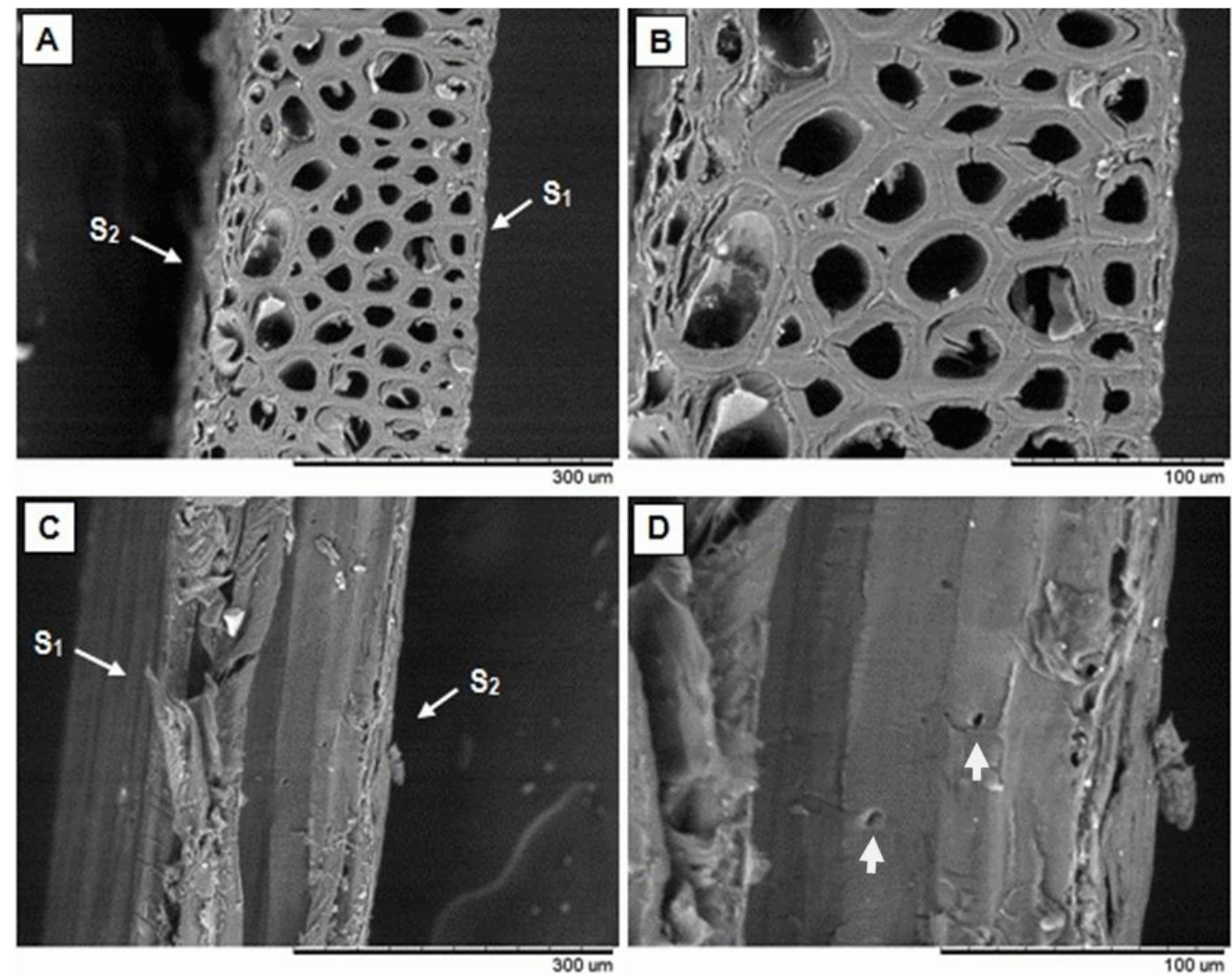

Figure 2. Scanning Electron Microscopy of exotesta on cross (A-B) and longitudinal (C-D) sections. $S_{1}$ and $S_{2}=$ exotesta outer and inner surfaces. Arrows = details of pits. 

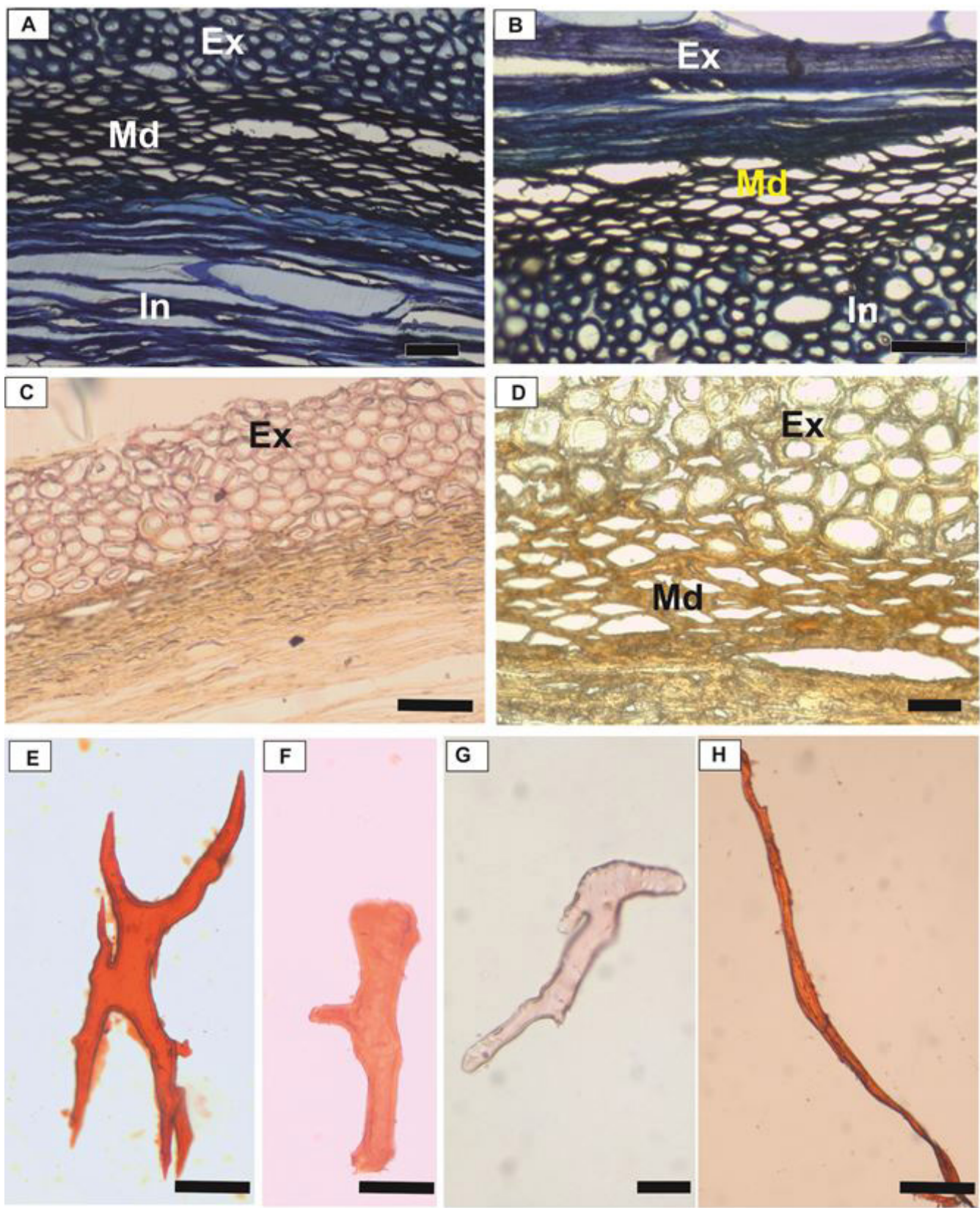

Figure 3. Anatomical features of mesotesta on cross (A, C and E) and longitudinal (B) sections, and dissociated material $(\mathrm{E}-\mathrm{H}) . \mathrm{A}-\mathrm{B}=$ Three regions, Toluidine blue stain; $\mathrm{C}=$ Lignified walls, Wiesner test; $\mathrm{D}=$ Second tissue (middle) with positive reaction to phenolic compounds, $10 \%$ Potassium dichromate; $\mathrm{E}=$ Ramiform sclereids; $\mathrm{F}=$ Macrosclereids; $\mathrm{G}=$ Macrosclereids; $\mathrm{H}=$ Filiform sclereids. $\mathrm{Ex}=$ External; $\mathrm{Md}=$ Middle; In = Inner. Bars $=25 \mu \mathrm{m}(\mathrm{A}, \mathrm{G}) ; 30 \mu \mathrm{m}(\mathrm{D}) ; 125 \mu \mathrm{m}(\mathrm{B}, \mathrm{C}, \mathrm{E}, \mathrm{F}$ and $\mathrm{H})$.

$\sim 1370 \mathrm{~cm}^{-1}$ is attributed to cellulose and hemicellulose $\mathrm{C}-\mathrm{H}$ deformation. The absorption peak at $\sim 1450$ $\mathrm{cm}^{-1}$ is due to $\mathrm{O}-\mathrm{H}$ deformation in the plane of cellulose, hemicellulose and lignin. The absorption peak at $\sim 1160 \mathrm{~cm}^{-1}$ is attributed to the asymmetric stretching of cellulose and hemicellulose C-O-C.

\subsection{Color spectroscopy}

Statistical analysis indicated color significant differences between layers (Table 2). Lightness $\left(\mathrm{L}^{*}\right)$ is higher at the mesotesta outer surface $\left(\mathrm{S}_{3}\right)$ and endotesta inner surface $\left(\mathrm{S}_{6}\right)$, with mean values 
Table 2. Means of the color variables of the Araucaria angustifolia seed coat layers.

\begin{tabular}{|c|c|c|c|c|c|c|}
\hline Layer & & Lightness & Red hue & Yellow hue & Chroma & Hue angle \\
\hline \multirow{2}{*}{ Exotesta } & $\mathrm{S}_{1}$ & $\begin{array}{c}40.79 \\
{[85.41] \mathrm{c}}\end{array}$ & $\begin{array}{c}19.95 \\
{[199.70] \mathrm{b}}\end{array}$ & $\begin{array}{c}18.80 \\
{[116.54] \mathrm{b}}\end{array}$ & $\begin{array}{c}27.47 \\
{[142.34] b c}\end{array}$ & $\begin{array}{c}43.07 \\
{[98.88] \mathrm{b}}\end{array}$ \\
\hline & $\mathrm{S}_{2}$ & $\begin{array}{c}49.03 \\
{[180.97] \mathrm{b}}\end{array}$ & $\begin{array}{c}15.72 \\
{[58.57] \mathrm{e}}\end{array}$ & $\begin{array}{c}20.99 \\
{[174.48] \mathrm{a}}\end{array}$ & $\begin{array}{c}26.28 \\
{[102.27] \mathrm{cd}}\end{array}$ & $\begin{array}{c}53.05 \\
{[211.82] \mathrm{a}}\end{array}$ \\
\hline \multirow{2}{*}{ Mesotesta } & $\mathrm{S}_{3}$ & $\begin{array}{c}53.02 \\
{[227.97] \mathrm{ab}}\end{array}$ & $\begin{array}{c}16.41 \\
{[87.63] \mathrm{de}}\end{array}$ & $\begin{array}{c}23.20 \\
{[223.43] \mathrm{a}}\end{array}$ & $\begin{array}{c}28.47 \\
{[170.64] \mathrm{b}}\end{array}$ & $\begin{array}{c}54.57 \\
{[230.76] \mathrm{a}}\end{array}$ \\
\hline & $\mathrm{S}_{4}$ & $\begin{array}{c}41.90 \\
{[100.70] \mathrm{c}}\end{array}$ & $\begin{array}{c}18.21 \\
{[155.59] \mathrm{bc}}\end{array}$ & $\begin{array}{c}16.92 \\
{[66.61] \mathrm{b}}\end{array}$ & $\begin{array}{c}24.88 \\
{[65.83] \mathrm{d}}\end{array}$ & $\begin{array}{c}42.85 \\
{[93.26] \mathrm{b}}\end{array}$ \\
\hline \multirow{2}{*}{ Endotesta } & $\mathrm{S}_{5}$ & $\begin{array}{c}37.15 \\
{[34.63] \mathrm{d}}\end{array}$ & $\begin{array}{c}24.84 \\
{[267.61] \mathrm{a}}\end{array}$ & $\begin{array}{c}16.99 \\
{[70.21] \mathrm{b}}\end{array}$ & $\begin{array}{c}30.12 \\
{[221.51] \mathrm{a}}\end{array}$ & $\begin{array}{c}34.28 \\
{[25.53] \mathrm{c}}\end{array}$ \\
\hline & $\mathrm{S}_{6}$ & $\begin{array}{c}53.75 \\
{[239.64] \mathrm{a}}\end{array}$ & $\begin{array}{c}17.04 \\
{[116.14] \mathrm{cd}}\end{array}$ & $\begin{array}{c}22.65 \\
{[217.32] \mathrm{a}}\end{array}$ & $\begin{array}{c}28.37 \\
{[173.58] \mathrm{ab}}\end{array}$ & $\begin{array}{c}53.02 \\
{[208.54] \mathrm{a}}\end{array}$ \\
\hline
\end{tabular}

Values between brackets $=$ Kruskal-Wallis mean ranks. Means with same letter are not statistically different. $\mathrm{S}_{1}$ and $\mathrm{S}_{2}=$ exotesta outer and inner surfaces; $\mathrm{S}_{3}$ and $\mathrm{S}_{4}=$ mesotesta outer and inner surfaces; $\mathrm{S}_{5}$ and $\mathrm{S}_{6}=$ endotesta outer and inner surfaces.
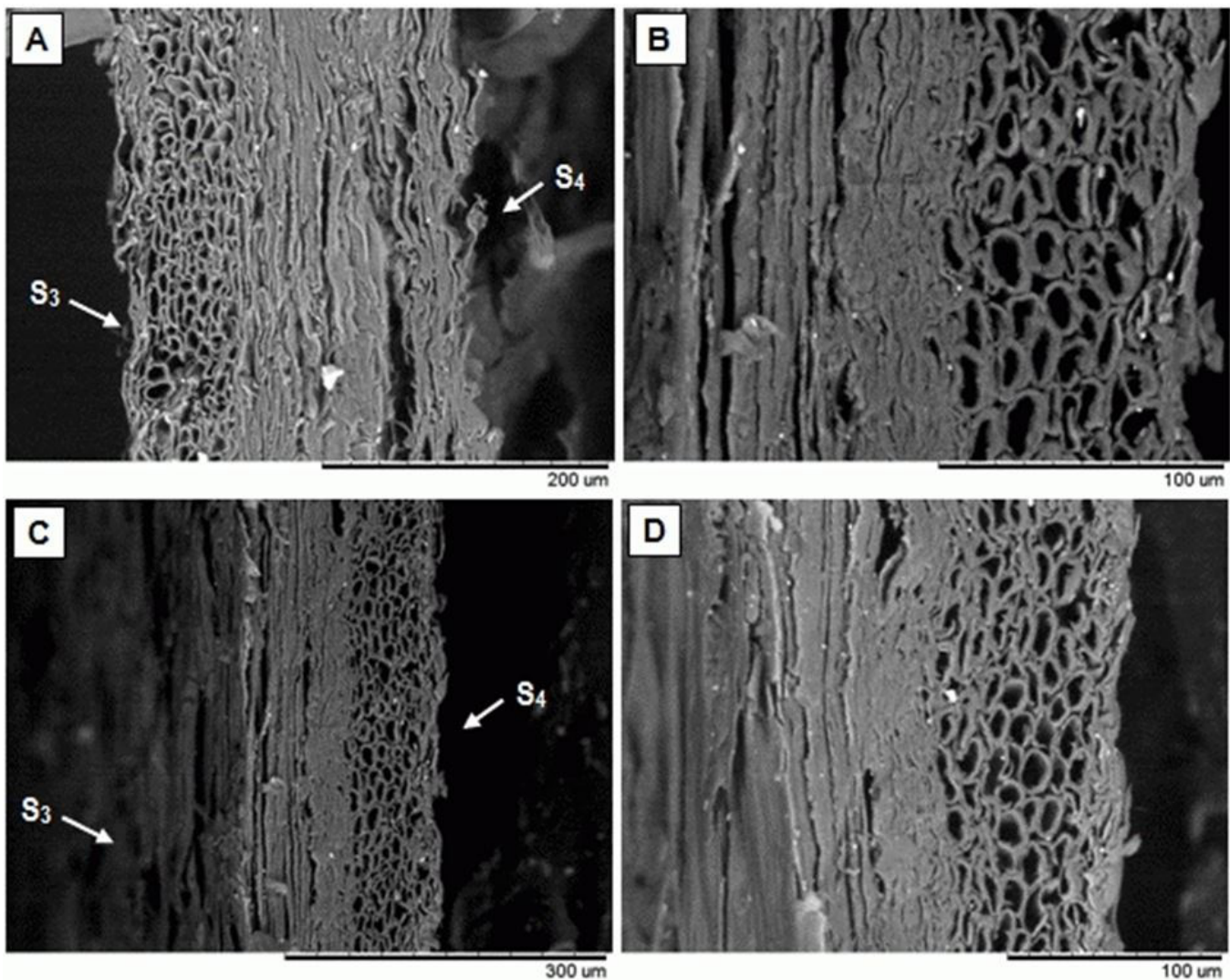

Figure 4. Scanning Electron Microscopy of mesotesta on cross (A-B) and longitudinal (C-D) sections. $\mathrm{S}_{3}$ and $\mathrm{S}_{4}=$ mesotesta external and internal surfaces.

of 53.02 and 53.75, respectively. The endotesta outer surface $\left(\mathrm{S}_{5}\right)$ is the darkest layer, i.e., exhibits the lowest lightness with a mean value of 37.15 . By comparing the inner and outer surfaces of each layer, it is possible to note that the exotesta inner surface $\left(S_{2}\right)$ is lighter (higher $L^{*}$ value) than the exotesta outer surface $\left(S_{1}\right)$; in mesotesta, the inner surface $\left(\mathrm{S}_{4}\right)$ is darker than outer surface $\left(\mathrm{S}_{3}\right)$; and in the endotesta, the outer surface $\left(S_{5}\right)$ is darker than the inner surface $\left(\mathrm{S}_{6}\right)$. Chroma $\left(\mathrm{C}^{*}{ }_{\mathrm{ab}}\right)$ indicates color saturation, i.e., the higher the $\mathrm{C}^{*}{ }_{\mathrm{ab}}$, the more saturated the color. In this sense, the outer $\left(\mathrm{S}_{5}\right)$ and 
Table 3. Means of the apparent contact angle of the Araucaria angustifolia seed coat layers.

\begin{tabular}{|c|c|c|c|c|c|c|c|}
\hline \multirow{2}{*}{ Layer } & & \multicolumn{2}{|c|}{$\begin{array}{c}\text { Mean contact angle } \\
\text { (degrees) }\end{array}$} & \multicolumn{2}{|c|}{$\begin{array}{l}\text { Initial contact angle } \\
\text { (degrees) - after } 15 \mathrm{~s}\end{array}$} & \multicolumn{2}{|c|}{$\begin{array}{c}\text { Final contact angle } \\
\text { (degrees) - after } 180 \mathrm{~s}\end{array}$} \\
\hline & & Mean & $\begin{array}{c}\text { Kruskal- } \\
\text { Wallis ranks }\end{array}$ & Mean & $\begin{array}{c}\text { Kruskal- } \\
\text { Wallis ranks }\end{array}$ & Mean & $\begin{array}{c}\text { Kruskal- } \\
\text { Wallis ranks }\end{array}$ \\
\hline \multirow{2}{*}{ Exotesta } & $\mathrm{S}_{1}$ & 77.80 & $129.10 \mathrm{c}$ & 79.93 & $122.71 \mathrm{c}$ & 79.79 & $113.73 \mathrm{~b}$ \\
\hline & $\mathrm{S}_{2}$ & 78.11 & $131.45 \mathrm{c}$ & 79.56 & $131.82 \mathrm{c}$ & 76.46 & $113.71 \mathrm{~b}$ \\
\hline \multirow{2}{*}{ Mesotesta } & $\mathrm{S}_{3}$ & 100.13 & $261.36 \mathrm{a}$ & 100.20 & $259.26 \mathrm{a}$ & 99.38 & $232.12 \mathrm{a}$ \\
\hline & $\mathrm{S}_{4}$ & 62.74 & $58.87 \mathrm{~d}$ & 64.90 & $59.27 \mathrm{~d}$ & 63.50 & $55.03 \mathrm{c}$ \\
\hline \multirow{2}{*}{ Endotesta } & $\mathrm{S}_{5}$ & 75.48 & $117.15 \mathrm{c}$ & 77.92 & $120.97 \mathrm{c}$ & 74.20 & $103.17 \mathrm{bc}$ \\
\hline & $\mathrm{S}_{6}$ & 88.80 & $205.07 \mathrm{~b}$ & 89.26 & $205.42 \mathrm{~b}$ & 87.80 & $185.07 \mathrm{a}$ \\
\hline
\end{tabular}

Means with same letter are not significantly different from each other. $S_{1}$ and $S_{2}=$ external and internal surfaces of the exotesta; $\mathrm{S}_{3}$ and $\mathrm{S}_{4}=$ external and internal surfaces of the mesotesta; $\mathrm{S}_{5}$ and $\mathrm{S}_{6}=$ external and internal surfaces of the endotesta.
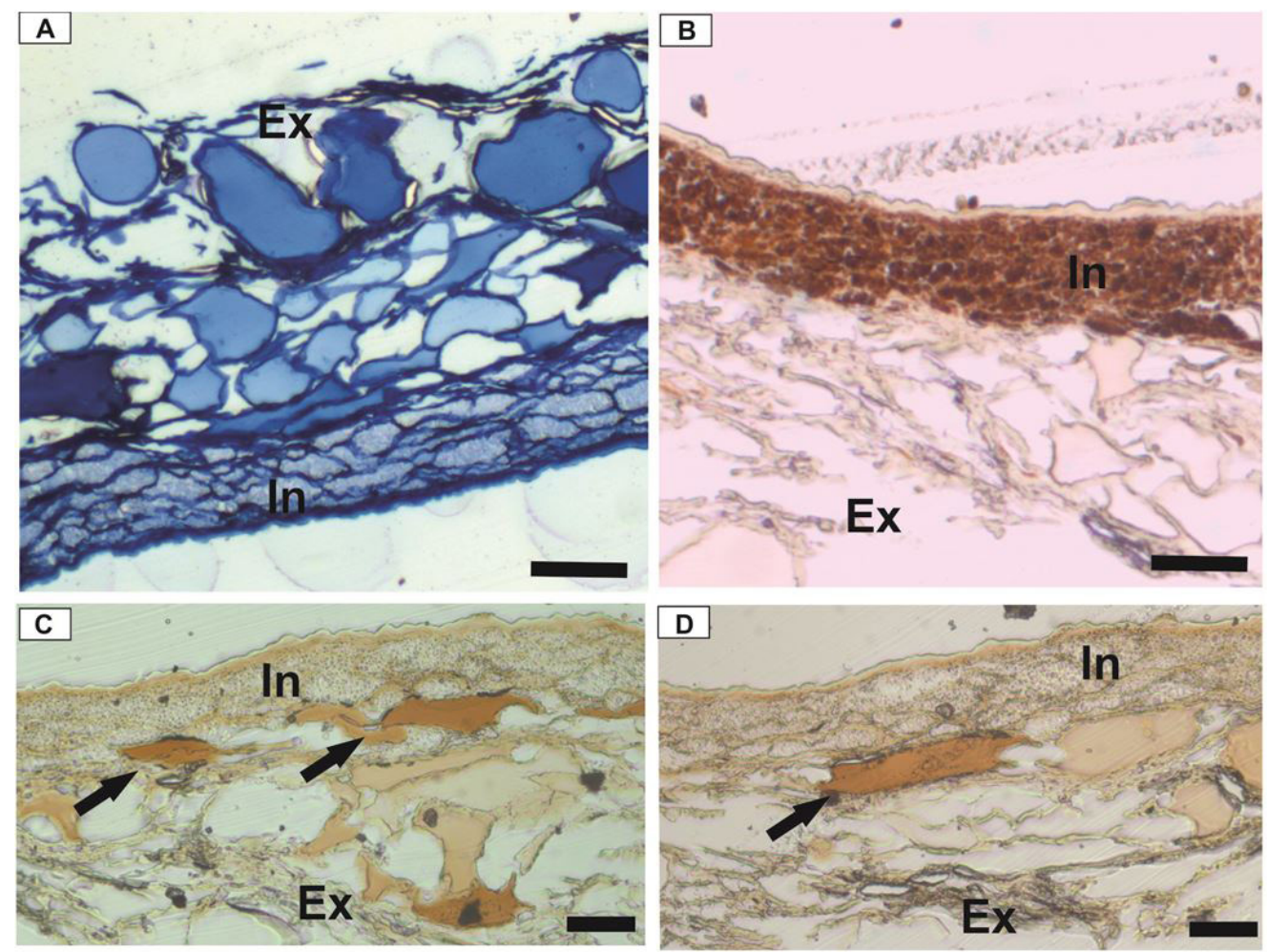

Figure 5. Anatomical features of endotesta on cross sections (A-D). A = Parenchymatous tissues, Toluidine blue stain; B = Parenchyma cells with starch grains, Lugol; C-D = Phenolic compounds on the external tissue (arrow), $10 \%$ Potassium dichromate. Ex = External; In = Inner. Bars = $125 \mu \mathrm{m}(\mathrm{A}-\mathrm{B}) ; 25 \mu \mathrm{m}(\mathrm{C}-\mathrm{D})$.

inner $\left(\mathrm{S}_{6}\right)$ endotesta surfaces exhibit the highest color saturation or higher chromaticity. $S_{5}$ presented more red hue $\left(a^{*}\right)$, whereas $S_{6}$ exhibited more yellow hue, which explains the higher $\mathrm{C}^{*}$ ab values. Hue angle $\left(\mathrm{h}_{\mathrm{ab}}\right)$, as well as red $\left(\mathrm{a}^{\star}\right)$ and yellow $\left(\mathrm{b}^{*}\right)$ hues, express tonality. The highest angles were found for $\mathrm{S}_{2}, \mathrm{~S}_{3}$ and $\mathrm{S}_{6}$ surfaces, which values were 53.05,
54.57 and 53.02, respectively, while $S_{5}$ exhibited the lowest angle (34.28). The $\mathrm{S}_{2}, \mathrm{~S}_{3}$ and $\mathrm{S}_{6}$ surfaces also present the highest values of yellow hue $\left(b^{*}\right)$.

\subsection{Contact angle}

Statistical analysis showed significant differences between wettability of the coat layers (Table 3 ). 

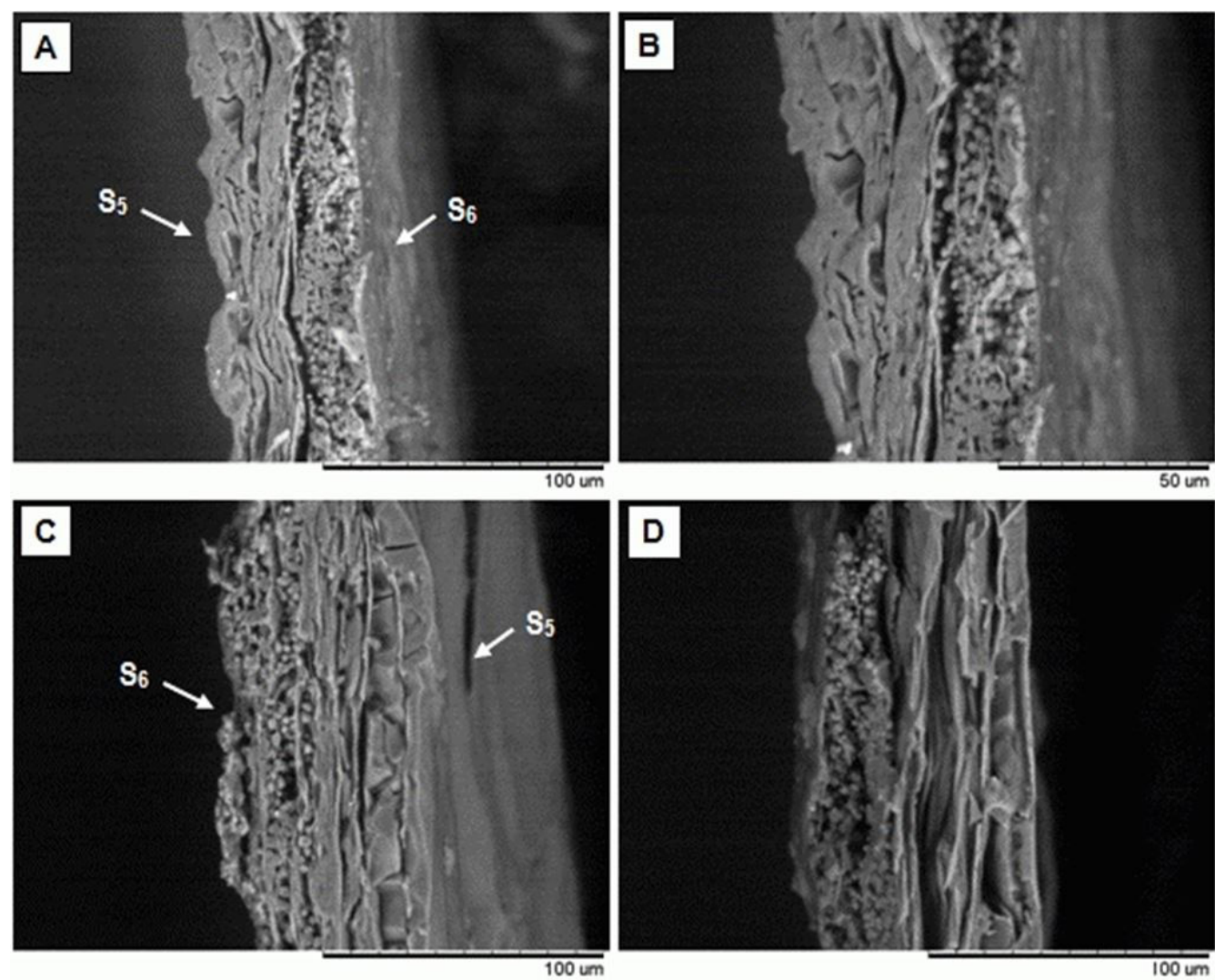

Figure 6. Scanning Electron Microscopy of endotesta on cross (A-B) and longitudinal (C-D) sections. $\mathrm{S}_{5}$ and $\mathrm{S}_{6}=$ endotesta outer and inner surfaces.

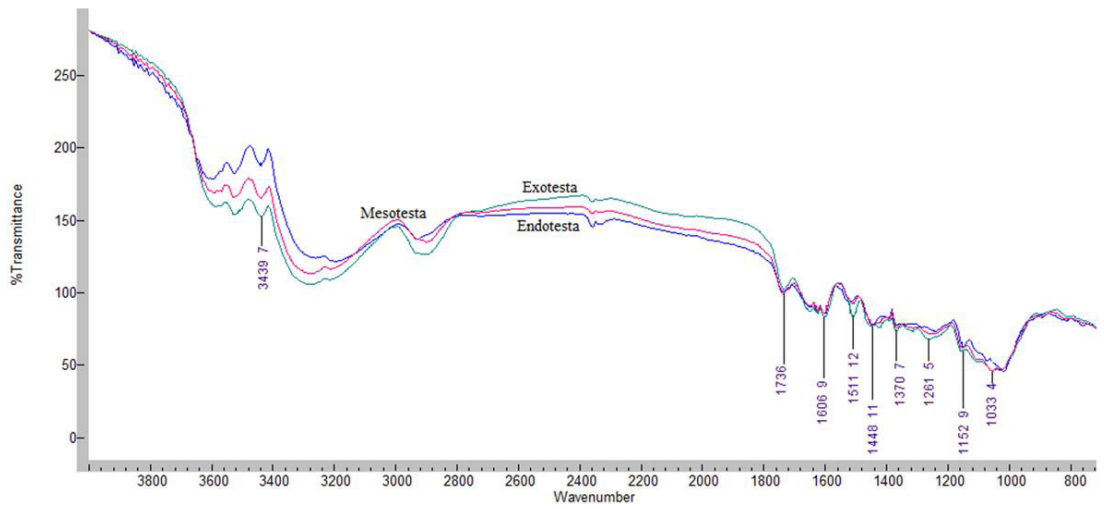

Figure 7. FT-IR spectra of the three layers of the Araucaria angustifolia seed coat.

\section{DISCUSSION}

Different tissues and extractive contents were organized and distributed in the three-layered seed coat of $A$. angustifolia. The secondary cell walls of the outermost layer have lipid compounds and the lignin, which are hydrophobic, and therefore prevent the entrance of water in the endosperm, which can difficult the pinhão seed germination. In the mesotesta, the sclereids and fiber-tracheids form net cells that are functional traits with a significant water barrier. 
In this study, phenolic compounds were detected by histochemical tests in external parenchymatous tissues of the endotesta. Branco et al. (2016) related the presence of catechin and quercetin among phenolic compounds of pinhão seed. Catechin may form polymeric proanthocyanidins, also called condensed tannins, which have antioxidant activity, controlling reactive oxygen species (ROS) levels and avoiding greater oxidative damages. Van Dongen et al. (2003) and Smýkal et al. (2014) refer to the amiliferous reserve observed in the endotesta innermost tissue as a "nutrient layer" which may support endosperma formation.

The morphologic and anatomic structure studies of Araucaria angustifolia seed coat have similarities, as observed to Araucaria mirabilis (Spegazzini) Windhausen (Stockey, 1975). Three layers, named by Stockey (1975) as sarcotesta, sclerotesta and endotesta, composed seed coat of Araucaria miriabilis, an extinct conifer species from Patagonia (Argentina). The sarcotesta (outer layer) is formed by 3-4 elongated cells; the sclerotesta (middle layer) is formed by sclereids in a zigzag orientation; and the endotesta (inner layer) is composed by parenchymatic cells.

The extraction cycle realized is based on the eluotropic series, in which the cyclohexane withdraws non-polar compounds and the methanol withdraws polar compounds, i.e. polyphenols. The seed coat is rich in condensed polyphenols (Silva et al., 2014); these polyphenols present its highest concentration in endotesta. The extractive total content was lower in the exotesta and higher in the endotesta.

The infrared spectrum of the pinhão seed coat exhibits characteristic signals indicating the presence of cellulose, hemicellulose and lignin, as found by several authors for vegetal biomass (Kubo \& Kadla, 2005; Sills \& Gossett, 2011; Xu et al., 2013). We observed peak at $1500 \mathrm{~cm}^{-1}$, considered by Lin \& Dence (1992) as a pure band and used as an internal standard in lignin spectra due to the absence of disturbance in its intensity. Specific vibrations for the different lignin structural units occur in the region below $1500 \mathrm{~cm}^{-1}$. Characteristic peaks of guaiacilic units can be noted in the spectrum, from which $\sim 1265 \mathrm{~cm}^{-1}$ band is attributed to $\mathrm{C}-\mathrm{O}$ stretching of the aromatic ring, and $\sim 1033 \mathrm{~cm}^{-1}$ band represents the aromatic $\mathrm{C}-\mathrm{H}$ stretching in the plane. Through semi-quantitative comparison of band intensities, it is possible to classify lignins.
We observed that the guaiacilic units occur in higher proportion than siringilic units in the spectrum of the pinhão seed coat, which characterizes this lignin as guaiacilic (G), known to conifers (Wagner et al., 2015).

In the color spectroscopy, the outer $\left(\mathrm{S}_{5}\right)$ and inner $\left(\mathrm{S}_{6}\right)$ endotesta surfaces exhibited higher chromaticity, since color is a physical property affected by chemical composition, mainly due to extractive content and nature (Amusant et al., 2004; Pâques et al., 2012). Our results for seed coat chromaticity are in agreement with the extractive analysis, in which the endotesta showed higher content than exotesta and mesotesta, and the histochemical analysis found phenolic compounds in endotesta $S_{5}$.

The mesotesta outer surface $\left(\mathrm{S}_{3}\right)$ had the highest values of apparent contact angle for all medium contact angle, initial (after $15 \mathrm{~s}$ ) and final (180 s) angles, thus denoting the lowest wettability. On the other hand, the mesotesta inner surface $\left(\mathrm{S}_{4}\right)$ had the highest wettability, i.e. the lowest angle values. These results may be due to a contrast between anatomical structure and chemical composition of $\mathrm{S}_{3}$ and $\mathrm{S}_{4}$ : in $\mathrm{S}_{3}$ there are lignified cell walls, the cells are disposed axially to the seed length; whereas in $\mathrm{S}_{4}$, the cells are disposed transversally, i.e., perpendicular to the seed length. Thus, water absorption occurs differently between these faces, and the lignin may contribute to lower wettability in $S_{3}$ due to its hydrophobicity.

The apparent contact angle of the exotesta outer $\left(\mathrm{S}_{1}\right)$ and inner $\left(\mathrm{S}_{2}\right)$ surfaces, and the endotesta outer surface $\left(\mathrm{S}_{5}\right)$ did not show significant differences between each other. $S_{1}$ and $S_{2}$ are very similar in anatomical structure, which explains the same contact angle behavior. Histochemical analysis indicated high lignin content in the exotesta, as well as for mesotesta, thus it was expectable that the wettability of the exotesta would be as low as in the mesotesta $\mathrm{S}_{3}$, which was not observed. Araucaria angustifolia seed coat exhibits the rucose surface on the exotesta and longitudinal strips on the mesotesta. In rough surfaces, the contact angle formed between the tangent of the liquid-air interface and the apparent solid surface is called apparent contact angle $\left(\theta_{m}\right)$, and may have affected values of contact angle. According to Bormashenko et al. (2013), the [apparent] contact angle, in these cases, results from a complex combination of chemical composition and surface roughness. 
The contact angle performance of the three coat layers exhibited the same trend after $15 \mathrm{~s}$ and $180 \mathrm{~s}$. Our results contribute to a better understanding of seed coat permeability to water penetration, and consequently to A. angustifolia seed germination. Mechanical scarification to remove the securing end of the seed (cut $3 \mathrm{~mm}$ from the tip of the seed) is usually recommended for A. angustifolia seeds to accelerate and increase its germination potential (Caçola et al., 2006).

\section{CONCLUSIONS}

Some anatomical and chemical features were considered functional traits related to the germination and development of the pinhão seed. The mesotesta showed greater diversity and anatomical complexity and the endotesta presented highest polyphenols concentration. Endotesta outer $\left(\mathrm{S}_{5}\right)$ and inner $\left(\mathrm{S}_{6}\right)$ surfaces exhibited the highest color saturation (chromaticity). $S_{5}$ presented more red hue $\left(a^{*}\right)$ due to phenolic compounds, while $\mathrm{S}_{6}$ had more yellow hue. The seed coat layers showed different wettability behaviors. The chemical composition was not sufficient to explain the complex phenomenon of wettability.

\section{ACKNOWLEDGEMENTS}

The authors thank the Brazilian agencies National Counsel for Technological and Scientific Development $(\mathrm{CNPq})$ and State of Rio de Janeiro Research Foundation (FAPERJ) for financial support.

\section{SUBMISSION STATUS}

Received: 16 aug., 2017

Accepted: 25 may, 2018

\section{CORRESPONDENCE TO}

\section{Danielle Affonso Sampaio}

Departamento de Produtos Florestais, Instituto de Florestas, Universidade Federal Rural do Rio de Janeiro - UFRRJ, Rodovia BR 465, Km 07, s/n, Zona Rural, CEP 23890-000, Seropedica, RJ, Brasil

e-mail: danitheu@gmail.com

\section{FINANCIAL SUPPORT}

Coordenação de Aperfeiçoamento de Pessoal de Nível Superior (001); Fundação Carlos Chagas Filho de Amparo à Pesquisa do Estado do Rio de Janeiro.

\section{REFERENCES}

Abreu HS, Carvalho AM, Monteiro MBO, Pereira RPW, Silva HR, Souza KCA et al. Métodos de análise em química da madeira. Floresta e Ambiente 2006; 1-20.

Amusant N, Beauchene J, Fournier M, Janin G, Thevenon M. Decay resistance in Dicorynia guianensis Amsh: analysis of inter-tree and intra-tree variability and relations with wood colour. Annals of Forest Science 2004; 61(4): 373380. http://dx.doi.org/10.1051/forest:2004030.

Associação de Preservação do Meio Ambiente e da Vida - APREMAVI. Floresta com Araucárias [online]. Atalanta: APREMAVI; 2017 [cited 2017 Aug 16]. Available from: http://www.apremavi.org.br/floresta-com-araucarias/

Borges EEL, Silva RF, Borges RCG. Estudo da germinação de sementes de pinheiro brasileiro. In: Resumo do Congresso Brasileiro de Sementes, 1987; Brasília. Brasília: ABRATES; 1987. p. 134.

Bormashenko E, Grynyov R, Bormashenko Y, Drovi E. Cold radiofrequency plasma treatment modifies wettability and germination rate of plant seeds. In: Mittal KL, editors. Advances in contact angle, wettability and adhesion. Massachusetts: Wiley Online Library; 2013. http://dx.doi.org/10.1002/9781118795620.ch14.

Branco CS, Rodrigues TS, Lima ED, Calloni C, Scola G, Salvador, M. Chemical constituints and biological activies of Araucaria angustifolia (Bertol.) O. Ktze: a review. Journal of Organic \& Inorganic Chemistry 2016; 2(1): 1-10. http:// dx.doi.org/10.21767/2472-1123.100008.

Caçola AV, Amarante CVD, Fleig FD, Mota CS. Qualidade fisiológica de Araucaria angustifolia (Bertol.) Kuntze submetidas a diferentes condições de armazenamento e escarificação. Ciência Florestal 2006; 16(4): 391-398. http://dx.doi.org/10.5902/198050981920.

Cordoba LP, Ribeiro LS, Rosa LS, Lacerda LG, Schnitzler E. Effect of enzymatic treatments on thermal, rheological and structuralproperties of pinhão starch. Thermochimica Acta 2016; 642: 45-51. http://dx.doi.org/10.1016/j. tca.2016.08.020.

Costa FJOG, Leivas CL, Waszczynskyj N, Godoi RCB, Helm CV, Colman TAD et al. Characterisation of native starches of seeds of Araucaria angustifolia from four germplasm collections. Thermochimica Acta 2013; 565: 172-177. http://dx.doi.org/10.1016/j.tca.2013.04.030.

Doni L Fo, Amaral L, Cervi PH. Métodos para testar o poder germinativo das sementes de Araucaria angustifolia 
(Bert.) O. Ktze. Revista Brasileira de Sementes 1985; 7(2): 113-123. http://dx.doi.org/10.17801/0101-3122/rbs. v7n2p113-123.

International Organization for Standardization - ISO. ISO 11664-4:2008 (CIE S 014-4/E:2007) - Colorimetry -- Part 4: CIE $1976 L^{\star} a^{\star} b^{\star}$ Colour space [online]. Geneva: ISO; 2008 [cited 2017 Aug 16]. Available from: https://www. iso.org/obp/ui/\#iso:std:iso:11664:-4:ed-1:v1:en

Koen J, Slabbert MM, Bester C, Bierman F. Germination characteristics of dimorphic honeybush (Cyclopia spp.) seed. South African Journal of Botany 2017; 110: 68-74. http://dx.doi.org/10.1016/j.sajb.2016.03.006.

Kraus JE, Arduin M. Manual básico de métodos em morfologia vegetal. Seropédica: Editora Universidade Rural; 1997.

Kubo S, Kadla JF. Hydrogen bonding in lignin: a fourier transform infrared model compound study. Biomacromolecules 2005; 6(5): 2815-2821. http://dx.doi. org/10.1021/bm050288q. PMid:16153123.

Lin SY, Dence CW. Methods in lignin chemistry. Berlín: Spring-Verlag; 1992. http://dx.doi.org/10.1007/978-3642-74065-7.

Muhl QE, du Toit ES, Steyn JM, Robbertse PJ. The embryo, endosperm and seed coat structure of developing Moringa oleifera seed. South African Journal of Botany 2016; 106: 60-66. http://dx.doi.org/10.1016/j.sajb.2016.05.009.

Núcleo de Estudos e pesquisas em Alimentação - NEPA. Tabela Brasileira de Composição de Alimentos. Campinas: UNICAMP; 2011.

Pâques LE, García-Casas MDC, Charpentier JP. Distribution of heartwood extractives in hybrid larches and in their related European and Japanese larch parentes: relationship with wood colour parameters. European Journal of Forest Research 2012; 131(5): 1269-1278.

Peralta RM, Koehnlein EA, Oliveira RF, Correa VG, Corrêa RCG, Bertonha L et al. Biological activities and chemical constituents of Araucaria angustifolia: an effort to recover a species threatened by extinction. Trends in Food Science \& Technology 2016; 54: 85-93. http://dx.doi. org/10.1016/j.tifs.2016.05.013.

Sampaio DA, Abreu HS, Augusto LDS, Silva B, Ibanez CM. Perfil lignoídico del tegumento de semillas de Araucaria angustifolia. Bosque (Valdivia) 2016; 37(3): 549-555. http:// dx.doi.org/10.4067/S0717-92002016000300012.

Sills DL, Gossett JM. Assessment of commercial hemicellulases for saccharification of alkaline pretreated perennial biomass. Bioresource Technology 2011; 102(2): 1389-1398. http://dx.doi.org/10.1016/j.biortech.2010.09.035. PMid:20933396.

Silva CV, Martins G, Steiner N, Santos KL, Camargo RS, Mantovani A et al. Araucaria angustifolia PinheiroBrasileiro. In: Coradin L, Siminski A, Reis A, editores. Espécies Nativas da Flora Brasileira de Valor Econômico Atual ou Potencial Plantas para o Futuro - Região Sul. Brasília: Ministério do Meio Ambiente; 2011.

Silva SM, Koehnlein EA, Bracht A, Castoldi R, Morais GR, Baesso ML et al. Inhibition of salivary and pancreatic a-amylases by a pinhão coat (Araucaria angustifolia) extract rich in condensed tannin. Food Research International 2014; 56: 1-8. http://dx.doi.org/10.1016/j.foodres.2013.12.004.

Smýkal P, Vernoud V, Blair MW, Soukup A, Thompson $\mathrm{RD}$. The role of the testa during development and in establishment of dormancy of the legume seed. Frontiers in Plant Science 2014; 5(351): 1-19. http://dx.doi.org/10.3389/ fpls.2014.00351. PMID: 25101104.

Stockey RA. Seeds and embryos of Araucaria mirabilis. American Journal of Botany 1975; 62(8): 856-868. http:// dx.doi.org/10.1002/j.1537-2197.1975.tb14126.x.

Van Dongen JT, Ammerlaan AM, Wouterlood M, Van Aelst AC, Borstlap AC. Structure of the developing pea seed coat and the post-pholem transport pathway of nutrients. Annals of Botany 2003; 91(6): 729-737. https:// doi.org/10.1093/aob/mcg066.

Wagner A, Tobimatsu Y, Phillips L, Flint H, Geddes B, Lu $\mathrm{F}$ et al. Syringyl lignin production in conifers: proof of concept in a Pine tracheary element system. Proceedings of the National Academy of Sciences of the United States of America 2015; 112(19): 6218-6223. http://dx.doi. org/10.1073/pnas.1411926112. PMid:25902506.

Xu F, Yu J, Tesso T, Dowell F, Wang D. Qualitative and quantitative analysis of lignocellulosic biomass using infrared techniques: a mini-review. Applied Energy 2013; 104: 801-809. http://dx.doi.org/10.1016/j. apenergy.2012.12.019. 